УДК 351:342.5

DOI https://doi.org/10.32837/pyuv.v2i4(29).444

\begin{abstract}
Л. О. Кожура
orcid.org/0000-0003-4100-9530

кандидат юридичних наук, доиент,

професор кафедри теорії та історії права

ДВНЗ «Київський національний еконолічний університет ілені Вадила Гетьлана»
\end{abstract}

\title{
ІМПЛЕМЕНТАЦІЯ МІЖНАРОДНИХ НОРМ ЩОДО ЗАХИСТУ ПРАВ І СВОБОД ДІТЕЙ У НАЦІОНАЛЬНЕ ЗАКОНОДАВСТВО
}

Діти - це окрема, самостійна частина суспільства, якій притаманні особливі правила поведінки, своєрідні життєві погляди, що забезпечують їі розвиток, становлення й перетворення в дорослу частину суспільства.

Першим міжнародним актом, де вперше визнано права дитини як самостійного члена суспільства, є Женевська декларація прав дитини 1924 року. У Конвенції втілювався прогресивний погляд, що дитинство - це не підготовка до дорослого життя, а важливий і самоцінний етап життя людини. Норми цієї Декларації спрямовані на створення умов, що забезпечують нормальний фізичний і психічний розвиток дитини, право дитини на допомогу, належне виховання, захист.

Женевська Декларація 1924 року була захисним інструментом за своїм походженням. Власне, з 1924 року, після прийняття Декларації, права дитини ввійшли до системи міжнародного права, а сама Женевська декларація прав дитини стала наріжним каменем усього майбутнього міжнародного розвитку правових ініціатив стосовно прав дитини.

Женевська декларація прав дитини містить п'ять основних програмних пунктів: 1. Дитині повинні надаватися всі засоби, потрібні для їі нормального матеріального й духовного розвитку; 2. Голодна дитина повинна бути нагодована; хвора дитина має отримати допомогу; дитина, яка припустилася помилки, повинна бути виправлена; сироті чи безпритульній дитині має бути наданий притулок і догляд; 3. Дитина перша повинна отримувати допомогу під час лиха; 4. Дитина повинна мати дитинство й захист від усіх форм експлуатації; 5. Дитину потрібно виховувати в усвідомленні того, що її кращі якості мають бути спрямовані на благо ближнім [1].

Дещо пізніше прийнято Загальну декларацію прав людини, яку схвалили всі країни-учасниці Організації Об’єднаних Націй. Цим актом лише фрагментарно зачіпалися права дитини. Зокрема, ст. 25 визначалося, що материнство і дитинство дають право на особливе піклування й допомогу. Усі діти, народжені в шлюбі або поза шлюбом, повинні користуватися однаковим соціальним захистом. Також визначалося, що батьки мають право пріоритету у виборі виду освіти для своїх малолітніх дітей [2, ст. 25-26].

Після проголошення Загальної декларації прав людини Організація Об'єднаних Націй почала роботу над проектом Декларації прав дитини, яку прийняли 20 листопада 1959 року.

У Преамбулі Декларації прав дитини проголошено, що Генеральна Асамблея проголошує необхідність забезпечення дітям щасливого дитинства та користування передбаченими нею правами і свободами для їхнього особистого блага й блага суспільства, намагання дотримуватися цих прав шляхом законодавчих та інших заходів, що будуть поступово застосовуватися відповідно до принципів:

1. Дитина має бути наділена всіма правами, що визначені в Декларації прав дитини.

2 Дитині законом та іншими засобами має бути забезпечений спеціальний захист і надані можливості та сприятливі умови, що дадуть їй змогу розвиватися фізично, розумово, морально, духовно й соціально, здоровим і нормальним шляхом, в умовах свободи та гідності.

3. Дитині має належати від народження право на ім'я і громадянство.

4. Дитина має користуватися благами соціального забезпечення. Їй має належати право на здорове зростання й розвиток; із цією метою спеціальні догляд та охорона мають бути забезпечені дитині та її матері, зокрема належний допологовий і післяпологовий догляд.

5. Дитині, яка є неповносправною фізично, психічно або соціально, мають бути забезпечені спеціальні режим, освіта й піклування, необхідні з огляду на її особливий стан.

6. Дитина для повного й гармонійного розвитку іï особистості потребує любові та розуміння. Вона має, якщо це можливо, зростати в піклуванні та під відповідальністю своїх батьків, у будь-якому разі в атмосфері любові та моральної й матеріальної забезпеченості; малолітня дитина, крім випадків, коли є виняткові обставини, не має розлучатися зі своєю матір'ю. На суспільство й органи публічної влади має бути покладений обов'язок щодо здійснення особливого піклування про дітей, які не мають сім’ї, і про дітей, які не мають достатніх засобів існування. Бажано, щоб багато- 
дітним сім'ям надавалася державна або інша допомога на утримання дітей.

7. Дитина має право на здобуття освіти, яка має бути безоплатною та обов'язковою, щонайменше на початкових рівнях. Дитині має надаватися освіта, яка сприятиме її загальному культурному розвитку й завдяки якій вона зможе на основі рівності можливостей розвинути свої здібності та особистий світогляд, а також усвідомити моральну й соціальну відповідальність і стати корисним членом суспільства. Найкраще забезпечення інтересів дитини має бути керівним принципом для тих, хто несе відповідальність за їі освіту й навчання; насамперед таку відповідальність несуть їі батьки. Дитині має бути забезпечена повна можливість відпочинку та ігор, спрямованих на цілі освіти; суспільство й органи публічної влади повинні докладати зусиль для сприяння реалізації зазначеного права.

8. Дитина за будь-яких обставин має бути серед тих, які першими одержують захист і допомогу.

9. Дитина має бути захищена від усіх форм недбалого ставлення, жорстокості й експлуатації. Вона не повинна бути об'єктом торгівлі в будьякій формі. Дитина не може прийматися на роботу до досягнення належного вікового мінімуму; їй у жодному разі не повинні доручатися чи дозволятися роботи або заняття, які є шкідливими для ïï здоров'я або перешкоджають її освіті, фізичному, розумовому чи моральному розвитку.

10. Дитина має бути захищена від практики, яка може заохочувати расову, релігійну чи будьяку іншу форму дискримінації. Вона має виховуватися в дусі взаєморозуміння, толерантності, дружби між народами, миру й загального братерства, а також у повному усвідомленні, що її енергія та здібності мають бути присвячені служінню на користь інших людей [3].

У Конвенції про захист прав людини і основоположних свобод установлено, що право кожного на життя охороняється законом. Разом із тим ця Конвенція містить норми, що обмежують права дітей на свободу й особисту недоторканність. Зокрема, ст. 5 визначено, що кожен має право на свободу й особисту недоторканність. Нікого не може бути позбавлено свободи, крім таких випадків і відповідно до процедури, установленої законом, зокрема затримання неповнолітнього на підставі законного рішення з метою застосування наглядових заходів виховного характеру або законне затримання неповнолітнього з метою допровадження його до компетентного органу. Також визначено обмеження застосування принципу публічності в разі здійснення судового розгляду спору та прийняття й оголошення прийнятого рішення. Так, судове рішення проголошується публічно, але преса та публіка можуть бути не допущені в зал засідань протягом усього судового розгляду або його частини в інтересах моралі, громадського порядку чи на- ціональної безпеки в демократичному суспільстві, якщо того вимагають інтереси неповнолітніх або захист приватного життя сторін, або тією мірою, що визнана судом суворо необхідною, коли за особливих обставин публічність розгляду може зашкодити інтересам правосуддя [4].

20 листопада 1989 року Україна підписала Конвенцію про права дитини, яку ратифікувала Постановою Верховної Ради від 27 лютого 91 року № 789-XII.

Згідно з ч. 1 ст. 9 Конституції України, чинні міжнародні договори, згода на обов'язковість яких надана Верховною Радою України, $€$ частиною національного законодавства України. У контексті міжнародного права такі, серед іншого, документи, як декларації міжнародних організацій, належать до так званого «soft law» i з формально-юридичного погляду не є тим жорстким правом, яке зобов'язує державу діяти в певний спосіб. Водночас Декларація прав дитини визнається універсальним та ефективним механізмом та інструментом захисту прав дитини у світовому масштабі й діє з дати прийняття Резолюції Генеральної Асамблеї ООН від 20 листопада 1959 року. 27 лютого 1991 рокуУкраїноюратифікована Конвенція про права дитини від 20 листопада 1989 року, яка визначає основоположні засади у сфері захисту прав дитини. Крім того, згідно 3 Постановою Кабінету Міністрів України «Про порядок участі центральних органів виконавчої влади у діяльності міжнародних організацій, членом яких є Україна» від 13 вересня 2002 року № 1371, Міністерство соціальної політики України визначено головним відповідальним органом за співробітництво з Дитячим фондом ООН (ЮНІСЕФ) i комітетом ООН з прав дитини [5].

Так, відповідно до норм Конвенції про права дитини, дитина має права, які, на нашу думку, можна поділити так:

1. Соиіальні права: право на життя і здоровий розвиток дитини (ст. 6); право на реєстрацію зразу ж після народження й із моменту народження має право на ім'я та набуття громадянства, а також, наскільки це можливо, право знати своїх батьків і право на їх піклування (ст. 7); право дитини на збереження індивідуальності, включаючи громадянство, ім'я та сімейні зв' язки, як передбачається законом, не допускаючи протизаконного втручання (ст. 8); право дитина не розлучалася з батьками всупереч їхньому бажанню (ст. 9); возз'єднання сім'ї (ст. 10); право дитини на користування найбільш досконалими послугами системи охорони здоров'я та засобами лікування хвороб і відновлення здоров'я (ст. 24); право користуватися благами соціального забезпечення, включаючи соціальне страхування, і вживають необхідних заходів щодо досягнення повного здійснення цього права згідно з їхнім національним законодавством (ст. 26); 
право кожної дитини на рівень життя, необхідний для фізичного, розумового, духовного, морального й соціального розвитку дитини (ст. 27); право дитини на освіту (ст. 28); користуватися своєю культурою, сповідати свою релігію та виконувати їі обряди, а також користуватися рідною мовою (ст. 30); право дитини на відпочинок і дозвілля, право брати участь в іграх і розважальних заходах, що відповідають її віку, і вільно брати участь у культурному житті та займатися мистецтвом (ст. 31).

2. Право на захист: право на захист від незаконного переміщення й неповернення дітей із-за кордону (ст. 11); право на захист дитини від усіх форм фізичного та психологічного насильства, образи чи зловживань, відсутності піклування чи недбалого й брутального поводження та експлуатації, включаючи сексуальні зловживання, з боку батьків, законних опікунів чи будь-якої іншої особи, яка турбується про дитину (ст. 19); право на особливий захист і допомогу, що надаються державою (ст. 20); право на захист від незаконного зловживання наркотичними засобами та психотропними речовинами, як вони визначені у відповідних міжнародних договорах, і не допускати залучення дітей до протизаконного виробництва таких речовин і торгівлі ними (ст. 33); право на захист від усіх форм сексуальної експлуатації та сексуальних розбещень (ст. 34).

3. Політичні права: право вільно висловлювати ці погляди з усіх питань, що торкаються дитини, причому поглядам дитини приділяється належна увага згідно з її віком і зрілістю (ст. 12); право вільно висловлювати свої думки; це право включає свободу шукати, одержувати й передавати інформацію та ідеї будь-якого роду незалежно від кордонів в усній, письмовій чи друкованій формі, у формі творів мистецтва чи за допомогою інших засобів на вибір дитини (ст. 13); право дитини на свободу думки, совісті й релігії (ст. 14); право дитини на свободу асоціацій і свободу мирних зборів (ст. 15); доступ до інформації й матеріалів із різних національних і міжнародних джерел (ст. 17); право забезпечити дитині, яка бажає одержати статус біженця або яка вважається біженцем, відповідно до застосовуваних міжнародного або внутрішнього права й процедур (ст. 22).

4. Особисті права: право на особисте й сімейне життя, недоторканність житла, таємницю кореспонденції або незаконного посягання на їі честь і гідність; право на захист закону від такого втручання або посягання (ст. 16).

5. Еконолічні права: право дитини на захист від економічної експлуатації та від виконання будьякої роботи, яка може становити небезпеку для здоров'я, бути перешкодою в одержанні нею освіти чи завдавати шкоди її здоров'ю, фізичному, розумовому, духовному, моральному та соціальному розвитку (ст. 32) [6].
Отже, норми міжнародної Конвенції про права дитини є основоположними для норм країн-учасниць, які її прийняли. Україна, будучи країною-учасницею, приймаючи норми національного законодавства, імплементувала всі положення Конвенції про права дитини, виражені в таких законодавчих актах України, як Сімейний кодекс України; закони України: «Про охорону дитинства»; «Про забезпечення організаційно-правових умов соціального захисту дітей-сиріт та дітей, позбавлених батьківського піклування»; «Про біженців та осіб, які потребують додаткового або тимчасового захисту»; «Про оздоровлення та відпочинок дітей; «Про громадянство України»; «Про державну соціальну допомогу малозабезпеченим сім'ям»; «Про статус ветеранів війни, гарантії їх соціального захисту»; «Про державну допомогу сім' ям з дітьми»; «Про протидію поширенню хвороб, зумовлених вірусом імунодефіциту людини (ВІЛ), та правовий і соціальний захист людей, які живуть з ВІЛ»; «Про основи соціальної захищеності осіб з інвалідністю в Україні». Разом із тим невирішеним та актуальним залишається питання захисту прав і свобод дітей у деліктному процесі, що потребує особливої уваги та негайного вирішення, а також захисту їхніх прав і свобод у міжнародному праві.

\section{Jimepamypa}

1. Левченко К. Двадцять років Конвенції ООН про права дитини. URL: http://khpg.org/index. php?id=1258983351.

2. Загальна декларація прав людини : Міжнародний документ від 10.12.1948. URL: https://zakon.rada. gov.ua/laws/show/995_015/card2\#Card.

3. Декларація прав дитини : Міжнародний документ від 20.11.1959. URL: https://zakon.rada.gov.ua/ laws/show/995_384/card2\#Card.

4. Конвенція про захист прав людини і основоположних свобод : Міжнародний документ від 04.11.1950. URL: https://zakon.rada.gov.ua/laws/show/995_004/ card2\#Card.

5. Щодо надання роз'яснення : Лист Міністерства соціальної політики України від 19.09.2015 № Ш-16216/10.2. URL: https://zakon.rada.gov.ua/ laws/show/v10 2323-15.

6. Конвенція про права дитини : Міжнародний документ від 20.11.1989. URL: https://zakon.rada.gov. ua/laws/show/995_021.

\section{Анотація}

Кожура Л. О. Імплементація міжнародних норм щодо захисту прав і свобод дітей у національне законодавство. - Стаття.

У роботі розкрито систему міжнародних актів, які визначають права та свободи дітей. Запропоновано права дітей, що визначені в Конвенції про права дитини, поділити так: 1) соціальні права: право на життя та здоровий розвиток дитини (ст. 6); право на реєстрацію зразу ж після народження й із моменту народження має право на ім'я й набуття громадянства, а також, наскільки це можливо, право знати своїх батьків i право на їх піклування (ст. 7); право дитина не розлучалася з батьками всупереч їхньому бажанню (ст. 9); 
2) право на захист: право на захист від незаконного переміщення й неповернення дітей із-за кордону (ст. 11); право на захист дитини від усіх форм фізичного та психологічного насильства, образи чи зловживань (ст. 19); 3) політичні права: право вільно висловлювати ці погляди з усіх питань, що торкаються дитини, причому поглядам дитини приділяється належна увага згідно з їі віком і зрілістю (ст. 12); право вільно висловлювати свої думки (ст. 13); 4) особисті права: право на особисте й сімейне життя, недоторканність житла, таємницю кореспонденції або незаконного посягання на її честь і гідність; право на захист закону від такого втручання або посягання (ст. 16); 5) економічні права: право дитини на захист від економічної експлуатації та від виконання будь-якої роботи, яка може становити небезпеку для здоров'я, бути перешкодою в одержанні нею освіти чи завдавати шкоди її здоров'ю, фізичному, розумовому, духовному, моральному та соціальному розвитку (ст. 32).

Акцентовано увагу, що невирішеним та актуальним залишається питання захисту прав і свобод дітей у деліктному процесі, що потребує особливої уваги та негайного вирішення, а також захисту їхніх прав і свобод у міжнародному праві.

Ключові слова: дитина, права дитини, охорона прав дитини, міжнародні акти, імплементація норм міжнародного права.

\section{Summary}

Kozhura L. O. Implementation of international norms for the protection of the rights and freedoms of children in national legislation. - Article.

The paper describes a system of international acts that determine the rights and freedoms of children.
It is proposed that the rights of the children defined in the Convention on the Rights of the Child be divided as follows: 1 . social rights: the right to life and the healthy development of the child (Article 6); the right to register immediately after birth and from the moment of birth has the right to name and acquire citizenship, as well as, as far as possible, the right to know one's parents and the right to care for them (Article 7); right, the child did not part with his parents contrary to their wishes (Article 9). 2. the right to protection: the right to protection from the illegal movement and non-return of children from abroad (Article 11); the right to protect the child from all forms of physical and psychological abuse, abuse or abuse (Article 19). 3. political rights: the right to express freely these views on all matters affecting the child, with the views of the child being given due consideration in accordance with her age and maturity (Article 12); the right to express their opinions freely (Article 13). 4. personal rights: the right to privacy and family life, inviolability of housing, secrecy of correspondence or unlawful encroachment on her honor and dignity; the right to defend the law against such interference or encroachment (Article 16). 5 . economic rights: the right of the child to protect himself from economic exploitation and from the performance of any work that may endanger health, interfere with his education or harm his health, physical, mental, spiritual, moral and social development (Article 32).

It is emphasized that the issue of protection of the rights and freedoms of children in tort is still unresolved and urgent, which requires special attention and immediate resolution, as well as the protection of their rights and freedoms in international law.

Key words: child, child rights, protection of child rights, international acts, implementation of international law. 